\title{
Molecular Characterization of the Ro/SS-A Autoantigens
}

\author{
Daniel P. McCauliffe and Richard D. Sontheimer
}

\begin{abstract}
Molecular techniques have recently revealed that there are several immunologically distinct Ro/SS-A antigens. Three genes encoding putative Ro/SS-A protein antigens with calculated masses of 46, 52, and $60 \mathrm{kD}$ have been isolated. The encoded amino acid sequence of each is quite dissimilar. The $46-\mathrm{kD}$ antigen is calreticulin (CR), a highly conserved calcium-binding protein that resides predominately in the endoplasmic reticulum where it may be involved in protein assembly. Although CR has recently been confirmed to be a new human rheumatic disease-associated autoantigen, its relationship to the other components of the Ro/SS-A ribonucleoprotein has become somewhat controversial owing predominately to the fact that recombinant forms of calreticulin have not displayed the same pattern of autoantibody reactivity possessed by the native form of this protein. The $52-\mathrm{kD}$ antigen most likely resides in the nucleus and may be involved in the regulation of gene expression. The cellular location and function of the $60-\mathrm{kD}$ antigen is uncertain but studies indicate that it is a RNAbinding protein. The $46-$ and $60-\mathrm{kD}$ antigens share homology with foreign polypeptides, suggesting that an immune response initially directed against a foreign protein may give rise to the autoimmune response directed at cross-reacting self proteins. J Invest Dermatol 100:73S-79S, 1993
\end{abstract}

In 1969 Clark et al first demonstrated a novel antigen in human tissue extracts that by immunodiffusion analysis reacted with sera from patients with systemic lupus erythematosus and Sjögren's syndrome [1]. This antigen and its reactive autoantibodies were called Ro (auto)antigen and Ro (auto)antibodies, respectively. In 1975 Alspaugh and Tan similarly demonstrated the presence of three different autoantibodies in sera from patients with Sjögren's syndrome that they designated SS-A, SS-B, and SS-C [2]. Later it was demonstrated that SS-A autoantibodies were immunologically equivalent to the Ro autoantibodies [3], and thus we now commonly preface these autoantibodies and their respective antigens with the term Ro/SS-A. SS-B autoantibodies were also shown to be identical to La autoantibodies, a specificity that frequently accompanies Ro/SS-A autoantibodies [3].

\section{CLINICAL SIGNIFICANCE OF THE Ro/SS-A ANTIGENS AND ANTIBODIES}

The Ro/SS-A antigens are of clinical interest in that antibodies directed against them are found in the majority of patients with primary Sjögren's syndrome, subacute cutaneous lupus erythematosus (SCLE), neonatal lupus erythematosus (NLE), anti-nuclear antibody (ANA) negative lupus erythematosus (LE), and systemic LE-like disease secondary to homozygous C2 or C4 complement deficiency [4-9]. Substantial evidence indicates that they play a major role in the pathogenesis of disease $[10,11]$. The strongest evidence comes from observations in patients with NLE. Pregnant mothers with circulating Ro/SS-A autoantibodies can pass

Department of Dermatology (DPM), University of North Carolina, Chapel Hill, North Carolina; and Department of Dermatology and Internal Medicine (RDS), University of Texas Southwestern Medical Center, Dallas Texas, USA

Reprint requests to: Dr. Daniel P. McCauliffe, Department of Dermatology, CB 7600, Room 137 North Carolina Memorial Hospital, Chapel Hill, 27514.

Abbreviations: ANA, anti-nuclear antibody; CDNA, complementary DNA; $C M V$, cytomegalovirus; $C R$, calreticulin; ELISA, enzyme-linked immunosorbent assay; ER, endoplasmic reticulum; GRP, glucose-regulated protein; $h Y R N A$, human cytoplasmic $R N A ; \quad L E$, lupus erythematosus $N L E$, neonatal lupus erythematosus; $P D I$, protein disulfide isomerase; $R N P$, ribonucleoprotein; SCLE, subacute cutaneous lupus erythematosus; SDSPAGE, sodium dodecyl sulfate polyacrylamide gel electrophoresis; UV, ultraviolet; VSV, vesicular stomatitis virus them across the placenta to their fetus. The fetus can develop congenital heart block, hepatic inflammation, and thrombocytopenia from tissue injury presumably caused by these antibodies [12,13]. Additionally, shortly after birth and perhaps triggered by ultraviolet (UV) light exposure, these infants can develop skin lesions clinically and histopathologically similar to those of SCLE [12]. In several months, as the maternally acquired antibodies are cleared from the infant's circulation, the skin lesions resolve [12].

Investigative work has provided additional evidence that Ro/SS-A antibodies may be pathogenic. Ro/SS-A antibodies administered intravenously to immunodeficient mice engrafted with human skin bind preferentially in and about the human basal keratinocytes [14]. This binding is augmented by UV light exposure. This pattern of immunoglobulin deposition is identical to that found in biopsies from NLE and SCLE skin lesions.

\section{CHARACTERIZATION OF THE Ro/SS-A ANTIGENS}

Since Clark et al first demonstrated the presence of Ro/SS-A autoantibodies by immunodiffusion studies in 1969[1], we have learned a great deal more about their target antigens.

In 1981 Lerner et al demonstrated that human Ro/SS-A autoimmune sera immunoprecipitated a novel class of small RNAs that they designated the human (h) cYtoplasmic (Y) RNAs or hY RNA [15]. In 1984 Wolin and Steitz showed that this hY RNA immuno-precipitation resulted from the binding of Ro/SS-A autoantibodies to a $60-\mathrm{kD}$ protein to which the hY RNAs were apparently linked [16]. From 1984 until 1988 it was generally thought that Ro/SS-A autoantibodies were directed at a single $60-\mathrm{kD}$ protein. However, in 1988 Ben-Chetrit et al demonstrated a novel 52-kD Ro/SS-A antigen by immunoblot analysis that was immunologically distinct from the 60-kD antigen [17]. In 1989 Rader et al demonstrated four immunologically distinct antigens that react with monospecific Ro/SS-A autoimmune sera [18]. Over the past four years genes encoding 60-, 46-, and 52-kD autoantigens have been isolated.

60-kD Ro/SS-A In 1988 Deutscher et al reported the cloning of a 60-kD Ro/SS-A antigen from a human placental complementary (CDNA) library [19]. In 1989 Ben-Chetrit et al [20] reported the cDNA sequence cloned from a human T-cell leukemia cDNA library that appeared to be a 
homologous gene or a differentially spliced version of the gene characterized by Deutscher et al. Deutscher's and Ben-Chetrit's sequences both encoded a $60-\mathrm{kD}$ protein that was identical except for several amino acids at the carboxy-terminus. Both amino acid sequences contain a zinc finger motif and a sequence motif common to RNA binding proteins $[19,20]$. Zinc fingers are thought to serve as a site of nucleic acid binding or protein binding [21].

There is no extensive sequence homology between the $60-\mathrm{kD}$ protein and other published protein sequences; however, six segments of this protein have limited homology to different portions of a vesicular stomatitis virus (VSV) nucleocapsid protein [22]. Five of these homologous regions have significant reactivity to human Ro/SS-A autoimmune sera by enzyme-linked immunosorbent assay (ELISA), which suggests that an immune response initially directed at the VSV protein or a similar viral protein might cross-react with the $60-\mathrm{kD}$ Ro/SS-A protein by way of its cross-reacting epitopes. VSV is not known to be particularly pathogenic in humans, but the data suggest that this VSV protein or a similar viral protein might elicit the Ro/SS-A autoimmune response. This is an example of "molecular mimicry" where a microbial protein is thought to trigger an immune response that cross-reacts with a self-antigen [23].

46-kD Ro/SS-A Our group isolated a CDNA from an Epstein-Barr virus transformed human B-cell line that encodes a protein reactive with human Ro/SS-A autoimmune sera [24]. The encoded $46-\mathrm{kD}$ protein migrates aberrantly at $60 \mathrm{kD}$ by sodium dodecylsulfate-polyacrylamide gel electrophoresis (SDS-PAGE). The amino acid sequence of this $46-\mathrm{kD}$ molecule reveals a hydrophobic leader sequence at its amino terminal typical of molecules transported into the endoplasmic reticulum (ER), and a KDEL carboxy terminal sequence that is classic for proteins that are retained in the ER $[24,27]$. This sequence is extremely homologous to murine and rabbit CR (94\% and 92\%, respectively) [28]. CR is a calcium-binding protein that resides in the endoplasmic and sarcoplasmic reticulum [29]. From this high degree of sequence homology and other data it has been concluded that the $46-\mathrm{kD}$ molecule is human CR $[28,30]$.

Recent evidence indicates that CR may be coordinately expressed with the glucose-regulated protein (GRP)78, GRP94, and protein disulfide isomerase (PDI) genes [31]. The protein products of all four of these genes are highly acidic, localize to the ER, and bind calcium [32]. GRP78 and GRP94 are highly homologous to heat-shock proteins $[33,34]$. Both of these proteins and PDI are thought to play a major role in protein assembly within the ER [33-35]. Thus, by implication, CR may also play a role in protein assembly.

It is also interesting to note that patients infected with Onchocerca volvulus, a filarial nematode that causes river blindness, sclerosing lymphadenitis, and dermatologic disease in humans residing in parts of Africa and Central America, have antibodies directed against the Ral-1 antigen, which is highly homologous to CR $[28,36]$. Although patients with this nematode are not at increased risk for developing Sjögren's syndrome or LE, this homology between CR and a filarial protein raises the possibility that a foreign Ro/SS-A protein equivalent might trigger the autoimmune Ro/SS-A antibody response seen in some patients with Sjögren's syndrome and several LE-related disorders. Drosophila melanogaster and the marine snail Aplysia californka have molecules similar to CR [28].

Work recently presented by other laboratories has now confirmed our initial suggestion that calreticulin is a rheumatic disease-associated autoantigen $[37,38]$. One group has found that an Escherichia coli recombinant form of human calreticulin reacted by ELISA with $40 \%$ of the serum samples from unselected SLE patients [37], whereas another group found $33 \%$ of their SLE sera to react with the same form of recombinant CR by Western blot [38]. Curiously, neither group found a significant correlation between anti-CR and anti-Ro/SS-A autoantibody levels in their SLE patient sera.

We have reason to believe that post-translational modification such as phosphorylation, perhaps through the augmentation of hY RNA binding, could also be relevant to the configuration of CR that is recognized by Ro/SS-A autoantibodies. Non-mammalian forms of recombinant CR are

\section{Table I. Characteristics of Three Ro/SS-A cDNA-} Encoded Products

\begin{tabular}{lllll} 
Protein & Location & Function & Homology & $\begin{array}{l}\text { Pathogenic } \\
\text { Role }\end{array}$ \\
\hline $60 \mathrm{kD}$ & $\begin{array}{l}\text { Nuclear? } \\
\text { Cytoplasmic? }\end{array}$ & RNA binding & $\begin{array}{l}\text { VSV } \\
\text { nucleocapsid } \\
\text { protein }\end{array}$ & $\begin{array}{l}\text { Molecular } \\
\text { mimicry? }\end{array}$ \\
\hline $46 \mathrm{kD}$ & $\begin{array}{l}\text { Predominantly } \\
\text { cytoplasmic } \pm \\
\text { nuclear }\end{array}$ & $\begin{array}{l}\mathrm{Ca}^{++} \text {binding } \\
\text { Protein folding? Ral-1 }\end{array}$ & $\begin{array}{l}\text { Calreticulin } \\
\text { Translocation } \\
\text { Parasite } \\
\text { homology? }\end{array}$ \\
\hline & $\begin{array}{l}\text { Predominantly } \\
\text { nuclear } \pm \\
\text { cytoplasmic }\end{array}$ & $\begin{array}{l}\text { Gene } \\
\text { regulation? }\end{array}$ & rfp, rpt-1 & \\
\hline
\end{tabular}

unlikely to possess the same pattern of RNA binding or phosphorylation that is displayed by the native configuration of CR present in mammalian cells. The concern that CR may not be a component of the Ro/SS-A RNP complex stems from the fact that recombinant forms of CR both in our laboratory (personal unpublished observation) and in others $[37,38]$ do not display the same degree of reactivity with Ro/SS-A autoantibodies that has previously been demonstrated with native human CR purified from human Wil-2 cells. We now have evidence that the protein-RNA binding site present on a subpopulation of CR molecules that bind hY RNA contributes to the structure that is being recognized by human anti-Ro/SS-A autoantibodies [39].

52-kD Ro/SS-A Chan et al and Itoh et al independently isolated the same cDNA sequence from two different human T-cell cDNA libraries that encodes a $52-\mathrm{kD}$ protein reactive with human Ro/SS-A autoimmune sera $[40,41]$. The amino acid sequence predicted by this cDNA contained leucine zipper and zinc finger binding motifs and also had significant homology with the human ret transforming protein and the murine T-cell regulatory protein rpt-1, which are thought to play a role in gene regulation $[40,41]$. These sequence motifs and homologies suggest that the $52-\mathrm{kD}$ Ro/SS-A molecule may be involved in gene regulation and thus probably resides in the nucleus.

There are no significant sequence homologies between the 60-, 46-, or 52-kD antigens (Table I). Despite the knowledge gained from analyzing the encoded amino acid sequences of each Ro/SS-A cDNA, there still remain a number of unanswered questions that several investigators have started to address.

Are These Antigens Structurally Associated and What Are Their Relationships to the hY RNAs? Ro/SS-A autoimmune sera from patients with LE and Sjögren's syndrome immunoprecipitate four hY RNAs (hYl, 3,4 , and 5) from human cell extracts [15] (see Fig 1). Antisera specific for either a $52-\mathrm{kD}$ or a $60-\mathrm{kD}$ protein have been shown to immunoprecipitate the hY RNAs from cellular extracts. However, in one study whenever $52-k D$ specific antibodies (not reactive to the $60-k D$ antigen by immunoblot analysis) were used, the hY RNAs and $52-\mathrm{kD}$ protein were precipitated along with a small amount of $60-\mathrm{kD}$ protein [17]. Thus it is not certain whether 1 ) the $52-\mathrm{kD}$ species binds the hY RNAs directly; 2 ) the $52-\mathrm{kD}$ protein is indirectly associated with the hY RNA through a direct association with a 60-kD hY RNA binding protein; or 3) the antibodies that appeared specific for the $52-\mathrm{kD}$ antigen by immunoblot may recognize a cross-reactive epitope on the native Ro/SS-A ribonucleoprotein (RNP) particle.

Deutscher et al have demonstrated that the $60-\mathrm{kD}$ Ro/SS-A protein directly associates with hY RNAs in reconstitution studies [19]. There is some evidence that CR associates with the hY RNA as suggested by UV cross-linking studies [24], immunoprecipitation of hY RNA by affinitypurified CR antisera [24], and the fact that onchocerciasis patient sera with CR reactive antibodies can immunoprecipitate hY RNA [42]. Additionally, preliminary data indicate that rabbit antisera raised against two synthetic peptides corresponding to different portions of the CR 


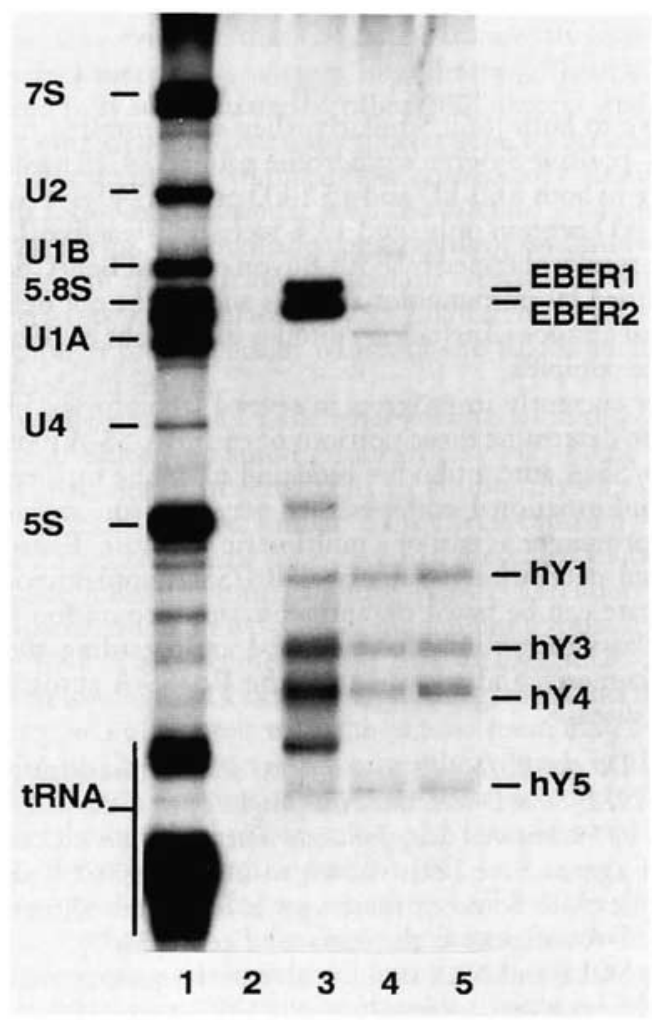

Figure 1. hY RNA immunoprecipitation. Wil-2 cells, an EBV transformed B-cell line, were radiolabeled with ${ }^{32} \mathrm{P}$-orthophosphoric acid and sonicated. The resulting cell extract was incubated with sera and the immunoprecipitated material was harvested and subjected to gel electrophoresis according to previously established protocols [15]. Lane 1 contains total radiolabeled RNA from the extract and serves to provide molecular weight standards as indicated to the left of this lane. Lane 2 demonstrates that no RNA was immunoprecipitated with normal human serum. Lane 3 is RNA immunoprecipitated with human autoimmune sera containing both Ro/SS-A and La/SS-B autoantibodies. Lanes 4 and 5 are sera from two different patients with Ro/SS-A autoantibodies as denned by double immunodiffusion. All three sera with Ro/SS-A autoantibodies immunoprecipitated the four major types of hY RNA. The very faint unlabeled band in lane 3 between $\mathrm{hYl}$ and $\mathrm{hY} 3$ is hY2, a breakdown product of hYl. The Epstein-Barr virus encoded EBER 1 and 2 immunoprecipitate with La/SS-B antibodies as previously described [56].

amino acid sequence can precipitate hYRNA [39]. However, the relationships that exist between $\mathrm{CR}$ and the other molecular constituents of the Ro/SS-A RNP particle continue to be debated $[38,43,44]$.

Earlier data suggested that Ro/SS-A autoimmune sera precipitated a 60-kD protein along with the hY RNA and this immunopre-cipitation was dependent on the presence of protein [15]. More recently Boire and Craft have identified Ro/SS-A antibodies that specifically immunoprecipitate hY5 RNA and a 60-kD protein, but not the other types of hY RNA [45]. They concluded that some Ro/SS-A autoimmune sera contain autoantibodies directed at a con-formational epitope that is expressed only on Ro/SS-A-hY5 RNA particles but absent on hY1, 2, 3, and 4 containing particles.

The $60-\mathrm{kD}$ protein immunoprecipitated in the above studies most probably represents the authentic $60-\mathrm{kD}$ protein as its amino acid sequence contains a sequence motif typically found in RNA-binding proteins, although it is clear that proteins without the classic RNAbinding consensus sequence can also bind RNA molecules $[46,47]$. The hY RNAs and Ro/SS-A proteins might exist in a RNP multimeric complex similar to the UI RNPs. One could hypothesize that the zinc finger motif in the $60-\mathrm{kD}$ Ro/SS-A molecule might serve as a site for this protein to

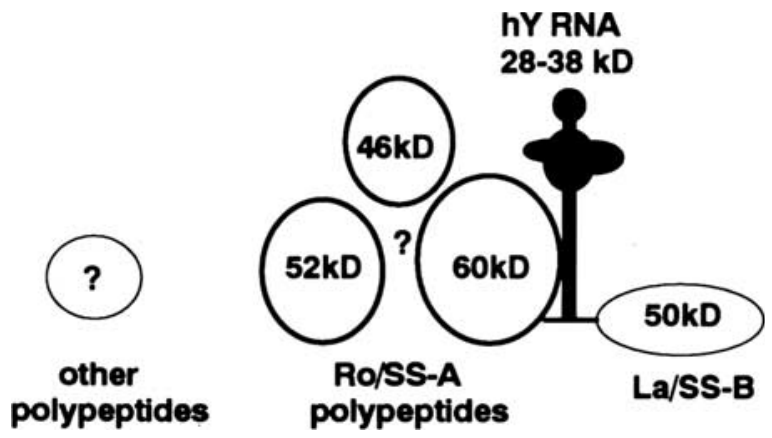

Figure 2. One model of the Ro/SS-A RNP particle. The proposed relationship between hY RNA and the Ro/SS-A and La/SS-B proteins is indicated. The hY RNA are RNA polymerase III transcripts and are thought to be at least transiently associated with the La/SS-B protein through binding of its uridine rich $3^{\prime}$ end. The $60-\mathrm{kD}$ Ro/SS-A protein contains an RNA binding motif believed to be the site of hY RNA binding. It is uncertain if the 46- and/or 52$\mathrm{kD}$ proteins reactive with Ro/SS-A autoimmune sera or other polypeptides are a part of this particle, although there is some evidence that the $46-\mathrm{kD}$ protein is associated with hY RNA.

bind one or more of the other Ro/SS-A molecules, whereas the RNA binding motif would serve as a site of hY RNA binding.

Several different investigators have reported different masses for the Ro/SS-A RNP particle. Three groups have reported a mass of approximately $100-150 \mathrm{kD}$ for the Ro/SS-A particle as determined by gel filtration $[1,48,49]$. Wolin and Steitz determined that the particle sediments in sucrose at approximately 7S [16]. This is equivalent to $\sim 93 \mathrm{kD}$, which could be accounted for by the mass of one $60-\mathrm{kD}$ protein and the average mass of one hY RNA molecule. Boire and Craft biochemically purified Ro/SS-A particles and found them to partition into three different groups by sucrose sedimentation gradients [50]. The particles in two of these groups have a mass of approximately $300-350 \mathrm{kD}$ by gel filtration and the other has a mass of approximately $230 \mathrm{kD}$. These investigators concluded that Ro/SS-A RNP particles are heterogeneous and may exist as multimeric units consisting of hY RNA, a $60-\mathrm{kD}$ protein, and perhaps other polypeptides including the La/SS-B protein [50] (see Fig 2).

Some investigators argue that if a particular protein reactive with Ro/ SS-A autoantibodies is not part of the hY RNA-bearing RNP complex, then perhaps it should not be called a Ro/SS-A antigen. Although this is a matter of semantics, there is a clear need to develop a more precise designation for each of these antigens. However, it should be remembered that Ro/SS-A antigens were initially defined by immunodiffusion assays, not by hY RNA association. It has not yet been determined which of the molecules reactive with Ro/SS-A autoimmune sera are responsible for the immunoprecipitate seen in immunodiffusion assays. Rader et al, however, observed that non-reducing SDS-PAGE of eluted precipitins from counter-immunoelectrophoresis showed the precipitins to be composed of a $60-k D$ protein [18].

What Is the Cellular Distribution of Each Ro/SS-A Molecule? Some investigators have reported predominantly intranuclear localization of the Ro/SS-A antigens by indirect immunofluorescence [51-54] whereas others have reported cytoplasmic [55-57] or both cyto-plasmic and nuclear localization $[58,59]$. Whether this discrepancy in subcellular localization is related to the method of cell fixation, cell substrate, or the specificity of the Ro/SS-A autoimmune sera used has not been fully investigated.

Koch et al have demonstrated that conventional cell fixation for ANA testing does not allow full visualization of proteins, such as CR, that reside in the ER [60]. They demonstrated that ER proteins can be better visualized by immunofluorescence techniques with detergent permeabilization of fixed cells or of unfixed cells that have been equilibrated in $9 \%$ sucrose $[60]$. 
Isolation of antibodies specific for each Ro/SS-A antigenic polypeptide has allowed more precise cellular localization of the Ro/SS-A polypeptides and these results have helped explain the discrepancies encountered previously with immunofluorescence staining using whole Ro/SS-A patient sera.

Ben-Chetrit et al demonstrated strong punctate nuclear and slight cytoplasmic staining of cells with Ro/SS-A autoimmune serum immunoaffinity purified from a $52-\mathrm{kD}$ protein and also with monospecific anti- 52-kD serum (as determined by immunoblot analysis) [17]. They reported an indistinguishable pattern with Ro/SS-A autoimmune serum immunoaffinity purified from a $60-\mathrm{kD}$ protein [17]. There is some evidence that there may be Ro/SS-A antibodies that react with an epitope on the native 60-kD RNP antigen that cross-react with an epitope on the $52-\mathrm{kD}$ protein [61]. Thus one might speculate that the $60-\mathrm{kD}$ protein resides primarily in the cytoplasm and that nuclear staining results from antibodies that recognize a cross-reactive epitope on the $52-\mathrm{kD}$ protein. Preliminary ELISA data have revealed that all Ro/SS-A autoimmune sera with high-titer antibodies directed against a recombinant 52-kD Ro/SS-A protein have given a speckled nuclear ANA pattern of fluorescence (personal unpublished observation). The 52-kD Ro/SS-A amino acid sequence reveals motifs and homologies that indicate that it may be involved in gene regulation and thus would likely reside in the nucleus $[40,41]$. Antiserum specific for CR has revealed predominantly perinuclear cytoplasmic staining with lesser amounts of nuclear staining $[62,63]$.

Kato et al have reported that the majority of the hY5 RNA is found in the cytoplasmic fraction of HeLa cells [64]. More recently Boire and Craft have demonstrated that more than $90 \%$ of the Ro/SS-A particles were recovered from the cytoplasmic fraction of HeLa cells [50]. One should recall that Ro/SS-A antigen was originally described as a saline-soluble, "cytoplasmic" autoantigen [1].

Is There Any Correlation Between the Type of Ro/SS-A Autoantibodies Patients Produce and Their Diagnosis, Disease Course, and/or Response to Therapy? Preliminary data suggest that patients with Ro/SS-A autoantibodies might be clinically categorized according to the Ro/ SS-A proteins or epitopes their sera recognize. The specificity of the maternally acquired Ro/SS-A autoantibodies may determine which infants develop NLE. Buyon et al have shown that the predominant antibody response in the NLE patient group with acquired heart block was directed against the $52-\mathrm{kD}$ Ro/SS-A protein, although some patients also had antibodies directed against a $60-\mathrm{kD}$ protein [65]. Ben-Chetrit et al have demonstrated that of 51 SLE patients who were Ro/SS-A positive by immunodiffusion, $47 \%$ had antibodies that recognized both a $60-\mathrm{kD}$ and a $52-\mathrm{kD}$ protein, $18 \%$ had antibodies that recognized a $60-\mathrm{kD}$ protein only, and $35 \%$ were nonreactive to both [66]. Similarly, they demonstrated that of $47 \mathrm{Ro} / \mathrm{SS}-\mathrm{A}$-positive Sjögren's syndrome patients, $47 \%$ had antibodies reactive to both a $60-\mathrm{kD}$ and a $52-\mathrm{kD}$ protein, $40 \%$ reacted only with a $52-\mathrm{kD}$ protein only, and $13 \%$ were non-reactive. Unfortunately the results obtained by both Buyon et al and Ben-Chetrit et al were obtained by immunoblot analysis and might not detect conformational epitopes, including epitopes that might be present on a multimeric complex.

Work is currently in progress in several laboratories, including our own, to determine those portions of each Ro/SS-A molecule to which Ro/ SS-A autoantibodies bind and to define further the nature of conformational epitopes that may exist on an individual Ro/SS-A protein or as part of a multimeric structure. Epitope mapping should determine if subsets of Ro/SS-A autoantibody-associated disease can be based on antigenic siterecognition patterns. Such subclassification may have clinical use regarding the pathogenesis, diagnosis, and treatment of the Ro/SS-A autoantibody-associated diseases.

What Role Do the Ro/SS-A Autoantigens Play in the Pathogenesis of SCLE and NLE Skin Disease and How Might Their Cellular Expression Be Affected by Factors that May Influence These Two Skin Diseases? A number of agents have been shown to influence SCLE and NLE disease

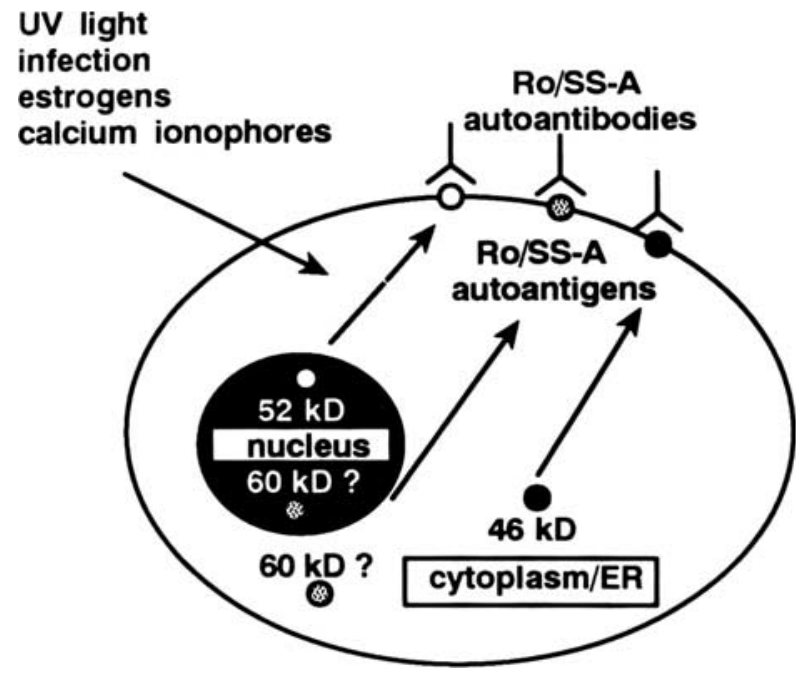

Figure 3. Ro/SS-A translocation. Agents that may translocate Ro/SS-A antigens to the cell surface where they are available to bind circulating Ro/SSA autoantibodies are listed. The likely predominant location of the 46- and $52-\mathrm{kD}$ antigens are indicated. The location of the $60-\mathrm{kD}$ antigen is more uncertain.

expression. Some of these agents have been shown to displace Ro/SS-A antigens to the surface of cells (Fig 3).

$U V$ light SCLE and NLE skin diseases are frequently exacerbated by UV light exposure, primarily of the UVB type $(290-320 \mathrm{nM})[67,68]$. Investigators have demonstrated that UVB light can displace Ro/SS-A antigen from within keratinocytes to the cell surface [69,70]. Similar results have recently been reported for the La/SS-B antigen [71]. Such displacement would allow the autoantigen to have access to the Ro/SS-A autoantibody binding that could result in tissue injury through complement-mediated lysis or antibody-dependent cell-mediated cytotoxicity. At this time it is uncertain which of the various molecular components of the Ro/SS-A autoantigen complex are affected by UV light exposure. Recent preliminary studies have indicated that physiologically relevant doses of UVB induce both CR gene transcription [72] (personal observation) and translation [73]. However, similar doses of UVB did not increase cellular levels of the $60-\mathrm{kD}$ Ro/SS-A protein [73]. No evidence has yet been presented regarding the displacement of the various Ro/SS-A proteins to the cell surface by UV light.

Estrogens The hormonal milieu may also play an important role in $\mathrm{Ro} /$ SS-A-associated disease, as approximately $75 \%$ of SCLE patients and infants with NLE skin disease are female. Estrogen treatment of cultured keratinocytes results in increased expression of Ro/SS-A antigens on the cell surface, but it is uncertain which of the Ro/SS-A molecules are so displaced [74].

Heat Some SCLE patients have noted that heat can exacerbate their skin disease [67]. The similarities that CR shares with the heat shock-like proteins GRP78 and GRP94 is of interest in this regard. There is recent evidence that heat shock - like proteins can be translocated to the cell surface, where they may participate in antigen presentation or may be a target for gamma/delta T-cell-directed cytotoxicity [75,76].

State of keratinocyte differentiation and proliferation Studies have shown that human keratinocytes grown in low-calcium-containing culture media have greater amounts of cytoplasmic Ro/SS-A antigen as detected by immunofluorescence staining with Ro/SS-A autoimmune sera [59]. It is uncertain which of the Ro/SS-A antigens are expressed in greater amounts, however. At lower calcium concentrations, cultured keratinocytes are in a less-differentiated, more rapidly proliferating state, more like the basal layer keratinocytes [77]. This might explain why the more rapidly proliferating basal keratinocytes appear to be preferentially targeted in SCLE and NLE $[11,78]$. Preliminary evidence indicates that CR 
is expressed at higher levels in rapidly proliferating cells (personal unpublished observation).

There is some evidence that CR can be transiently secreted from cells after treatment with calcium ionophores [79], although this has not been fully substantiated by others [80]. Recent studies in our laboratory employing calreticulin reporter gene constructs have indicated that calreticulin transcription is markedly augmented in A431 cells following treatment with the calcium ionophore ionomycin [72] (personal unpublished observation). Additionally, it has been suggested that calcium ionophore treatment of cultured human keratinocytes displaces Ro/SS-A antigen to the cell membrane, although it is uncertain which of the Ro/SS-A antigens is (are) so displaced [81].

Infection There is considerable evidence that viral infections can precipitate or exacerbate autoimmune disease [82]. Some work has suggested that virally infected cells in culture displace Ro/SS-A antigens to the cell surface, similar to the effects caused by UV light [83]. Jianhui and Newkirk have recently presented evidence that suggests that human cytomegalovirus (CMV) infection increases the expression of CR in MRC5, a human embryonic lung fibro-blast line [84]. These studies found that total cellular CR levels increased following CMV infection, but the greatest increase in $C R$ antigenicity was associated with the plasma membrane. CMV infection also resulted in increased intracellular levels of the $60-\mathrm{kD}$ Ro/SS-A antigen, but similar increases were not observed in the plasma membrane. Viral infection has also been shown to displace the La/SS-B antigen from the nucleus [85].

Polymorphism It is not known whether Ro/SS-A proteins are polymorphic. Preliminary studies have indicated, however, that the CR encoding gene is not highly polymorphic in normal individuals by restriction fragment length polymorphism analysis [24]. There is evidence of at least two forms of the $60-\mathrm{kD}$ Ro/SS-A encoding gene [18-20]. Kutsch et al have recently reported variability in Ro/SS-A displacement to keratinocyte membranes after treatment with calcium ionophore or tumor necrosis factor alpha, which they suggest might arise from genetic differences in the keratinocyte donors [81]. It is possible that certain forms of a Ro/SS-A molecule may be more immunogenic, expressed at higher levels, or more easily displaced to the cell surface where it could participate in immune-mediated injury.

\section{SUMMARY}

With molecular techniques, we have recently learned that there are several immunologically distinct Ro/SS-A antigens. Three putative Ro/SSA genes have been isolated and the encoded proteins from these three genes have been found to be quite dissimilar. CR, the $46-k D$ protein, appears to reside predominately in the endoplasmic reticulum/cytoplasm, whereas the $52-\mathrm{kD}$ protein most likely resides in the nucleus. The structure of the $60-\mathrm{kD}$ protein and at least one immunofluorescence study suggest that it may also reside predominantly in the nucleus, although if it is the authentic hY RNA binding protein, it should also reside in the cytoplasm. The Ro/SS-A RNP particles are heterogeneous multimeric complexes that may include more than one Ro/SS-A molecule, hY RNA, La/SS-B, and perhaps other currently undefined molecules.

Two of the putative Ro/SS-A proteins share significant homology with foreign proteins, suggesting that an immune response initially directed against a foreign protein, such as a viral protein, may give rise to the autoimmune response directed at cross-reacting self Ro/SS-A protein. This, plus the possibility that viral infection can alter the normal cellular distribution of Ro/SS-A antigens, presents the intriguing paradigm illustrated in Fig 4 where virus infection might have a dual impact on the Ro/SS-A autoimmune response.

Work is in progress to determine if there is an association between which Ro/SS-A molecules and/or epitopes are targeted by patient autoimmune sera and patient diagnosis, clinical course, and/ or response to therapy. We are hopeful that efforts to characterize the structures and functions of the Ro/SS-A antigens will further elucidate the pathogenesis of the Ro/SS-A autoantibody-associated diseases and aid in the

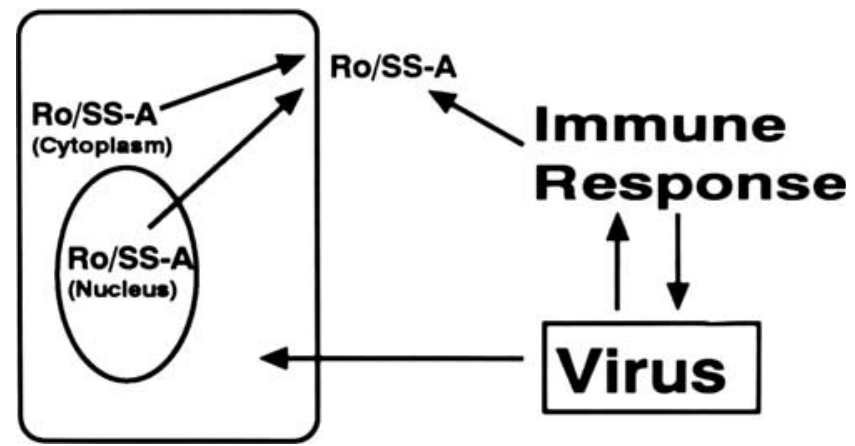

Figure 4. Model for a dual effect of virus infection on the Ro/SS-A autoimmune response. Infection with viruses that express molecules structurally associated with Ro/SS-A molecular subunits could result in translocation of Ro/SS-A antigens to the surface of cells. The immune response generated by the virus could then recognize the translocated Ro/SS-A antigens at the cell surface and mediate cellular damage through mechanisms such as complement-mediated lysis or antibody-dependent cell-mediated cytotoxicity.

development of better diagnostic and therapeutic modalities for those afflicted.

Dr. McCauliffe is the recipient of a Dermatology Foundation Career Development Award sponsored by Sandoz Pharmaceuticals and Dr. Sontheimer is the recipient of an NIH Research Career Development Award (ARO1784). This work was supported by NIH grant AR19101.

\section{REFERENCES}

1. Clark G, Reichlin M, Tomasi TB: Characterization of a soluble cytoplasmic antigen reactive with sera from patients with systemic lupus erythematosus. J Immunol 102:117-122, 1969

2. Alspaugh MA, Tan EM: Antibodies to cellular antigens in Sjögren's syndrome. J Clin Invest 55:1067-1073, 1975

3. Alspaugh MA, Maddison P: Relation of the identity of certain antigenantibody systems in systemic lupus erythematosus and Sjögren's syndrome: an interlaboratory collaboration. Arthritis Rheum 22:796-798, 1979

4. Martinez-Lavin M, Vaughan JH, Tan EM: Autoantibodies and the spectrum of Sjögren's syndrome. Ann Intern Med 91:185-190, 1979

5. Sontheimer RD, Maddison PJ, Reichlin M, Jordon RE, Stastny P, Gilliam JN: Serologic and HLA associations in subacute cutaneous lupus erythematosus, a clinical subset of lupus erythematosus. Ann Intern Med 97:664-671, 1982

6. Maddison PJ, Provost TT, Reichlin M: ANA negative systemic lupus erythematosus: serological analysis. Medicine (Baltimore) 60:87-94, 1981

7. Kephart D, Hood AF, Provost TT: Neonatal lupus: serologic findings. J Invest Dermatol 77:331-333, 1981

8. Provost TT, Arnett FC, Reichlin M: Homozygous C2 deficiency, lupus erythematosus and anti-Ro(SSA) antibodies. Arthritis Rheum 26:1279-1282, 1983

9. Meyer O, Hauptmann G, Tuppeiner G, Ochs HD, Mascart-Lemone F: Genetic deficiency of $\mathrm{C} 4, \mathrm{C} 2$ or $\mathrm{Clq}$ and lupus syndromes: association with anti-Ro(SS-A) antibodies. Clin Exp Immunol 62:678-684, 1985

10. McCauliffe DP, Lux F, Lieu TS, Sanz I, Hanke J, Newkirk M, Siciliano MJ Sontheimer RD, Capra JD: Ro/SS-A and the pathogenic significance of its antibodies. J Autoimmun 2:375-381, 1989

11. Sontheimer RD, McCauliffe DP: Pathogenesis of anti-Ro/SS-A autoantibody-associated cutaneous lupus erythematosus. Dermatol Clin 8:751-758, 1990

12. Lee LA, Weston WL: New findings in neonatal lupus syndrome. Am J Dis Child 138:233-236, 1984 
13. Laxer RM, Roberts EA, Gross KR, Britton JR, Cutz E, Dimmick J, Petty RE, Sil verman ED: Liver disease in neonatal lupus erythematosus. J Pediatr 116:238-242, 1990

14. Lee LA, Gaither KK, Coulter SN, Norris DA, Harley JB: Pattern of cutaneous immunoglobulin $\mathrm{G}$ deposition in subacute cutaneous lupus erythematosus is reproduced by infusing purified anti-Ro(SSA) autoantibodies into human skin-grafted mice. J Clin Invest 83:1556-1562,1989

15. Lerner MR, Boyle J, Hardin JA, Steitz JA: Two novel classes of small ribonucleoproteins detected by antibodies associated with lupus erythematosus. Science 211:400-402, 1981

16. Wolin SL, Steitz JA: The Ro small cytoplasmic ribonucleoproteins: identification of the antigenic protein and its binding site on the Ro RNA's. Proc Natl Acad Sci USA 81:1996-2000, 1984

17. Ben-Chetrit E, Chan EK, Sullivan KF, Tan EM: A 52-kD protein is a novel component of the SS-A/Ro antigenic particle. J Exp Med 167:1560-1571,1988

18. Rader MD, O'Brien C, Liu Y, Harley JB, Reichlin M: The heterogeneity of the Ro/SSA antigen: different molecular forms in lymphocytes and red blood cells. J Clin Invest 83:1293-1298, 1989

19. Deutscher SL, Harley JB, Keene JD: Molecular analysis of the $60-\mathrm{kDa}$ human Ro ribonucleoprotein. Proc Natl Acad Sci USA 85:9479-9483, 1988

20. Ben-Chetrit E, Gandy BJ, Tan EM, Sullivan KF: Isolation and characterization of a cDNA clone encoding the 60-kD component of the human SS-A/Ro ribonucleo-protein autoantigen. J Clin Invest 83:1284-1292, 1989

21. Frankel AD, Pabo C: Fingering too many proteins. Cell 53:675,1988

22. Scofield RH, Harley JB: Autoantigenicity of a Ro/SSA is related to a nucleocapsid protein of vesicular stomatitis virus. Proc Natl Acad Sci USA 88:3343-3347, 1991

23. Oldstone MBA: Molecular mimicry and autoimmune disease. Cell 50:819-820, 1987

24. McCauliffe DP, Lux FA, Lieu TS, Sanz I, Hanke J, Newkirk MM, Bachinski LL, Itoh Y, Siciliano MJ, Reichlin M, Sontheimer RD, Capra JD: Molecular cloning, expression, and chromosome 19 localization of a human Ro/SS-A autoantigen. J Clin Invest 85:1379-1391, 1990

25. Lingappa VR: Intracellular traffic of newly synthesized proteins. Current understanding and future prospects. J Clin Invest 83:739-751, 1989

26. Fliegel L, Burns K, Wlasichuk K, Michalak M: Peripheral membrane proteins of the sarcoplasmic and endoplasmic reticulum. Comparison of carboxy-terminal amino acid sequences. Biochem Cell Biol 67:696-702, 1989

27. Andres DA, Dickerson IM, Dixon JE: Variants of the carboxylterminal KDEL sequence direct intracellular retention. J Bio Chem 265:5952-5955, 1990

28. McCauliffe DP, Lieu T-S, Michalak M, Sontheimer RD, Capra JD: A human Ro/SS-A autoantigen is the homologue of calreticulin and is highly homologous with onchocercal Ral-1 antigen and an aplysia memory molecule. J Clin Invest 86:332-335, 1990

29. Smith MJ, Koch GL: Multiple zones in the sequence of calreticulin, a major calcium binding ER/SR protein. EMBO 8:3581-3586,1989

30. Lieu T-S, McCauliffe DP, Volpe P, Alderson-Lang BH, Michalak M, Capra JD, Sontheimer RD: Structural and functional homology between a human Ro/SS-A autoantigen and the calcium-binding protein, calreticulin (abstr). Clin Res 38:408A, 1990

31. McCauliffe DP, Yang YS, Wilson J, Sontheimer RD, Capra JD: The 5' flanking region of the human calreticulin gene is highly homologous with the human GRP78, GRP94 and protein disulfide isomerase promoters. J Biol Chem 267:2557-2562, 1992

32. Sambrook JF: The involvement of calcium in transport of secretory proteins from the endoplasmic reticulum. Cell 61:197-199, 1990

33. Munro S, Pelham HRB: An hsp70-like protein in the ER: identity with the $78 \mathrm{kD}$ glucose-regulated protein and immunoglobulin heavy chain binding protein. Cell 46:291-300, 1986

34. Sorger PK, Pelham HRB: The glucose-regulated protein grp94 is related to heat shock protein hsp90.JMol Biol 194:341-344,1987
35. Freedman RB: Protein disulfide isomerase: multiple roles in the modification of nascent secretory proteins. Cell 57:1069-1072, 1989

36. Lux FA, McCauliffe DP, Buttner DW, Capra JD, Sontheimer RD, Lieu TS: Antibodies to Onchocerca volvulus cross-react with a human Ro/SS-A autoantigen (abstr). Clin Res 38:626A, 1990

37. Hunter FA, Barger BD, Schrohenloher R, Koopman WJ, Dohlman JG: Autoantibodies to calreticulin in the sera of systemic lupus erythematosus (abstr). Arthritis Rheumat 34 (suppl 9):S75, 1991

38. Rokeach LA, Haselby JA, Meilof JF, Smeenk RJT, Unnasch TR, Greene BM, Hoch SO: Characterization of the autoantigen calreticulin. J Immunol 147:3031-3039, 1991

39. Lieu TS, Capra JD, Sontheimer RD: Calreticulin is a component of the human Wil-2 cell Ro/SS-A autoantigen complex (abstr). Clin Res 40:508A, 1992

40. Edward K, Chan L, Hamel JC, Buyon JP, Jan EM: Molecular definition and sequence motifs of the 52-kD component of human SS-A/ Ro autoantigen. J Clin Invest 87:68-76, 1991

41. Itoh K, Itoh Y, Frank MB: Protein heterogeneity in the human Ro/SSA ribonucleoproteins. The 52- and 60-kD Ro/SSA autoantigens are encoded by separate genes. J Clin Invest 87:117-186, 1991

42. Lux FA, McCauliffe DP, Buttner DW, Capra JD, Sontheimer RD, Lieu TS: Serologic cross-reactivity between a human Ro/SS-A autoantigen (calreticulin) and the Ral-1 antigen of Onchocerca volvulus. J Clin Invest 89:1945-1951, 1992

43. Lieu TS, McCauliffe DP, Volpe P, Alderson-Lang BH, Heilman C, Leberer E, Michalak M, Fliegel L, Capra JD, Sontheimer RD: Further evidence supporting the identity of a native human Wil-2 cell $46 \mathrm{kD}$ Ro/SS-A autoantigen with the highly conserved calcium binding protein, calreticulin (submitted for publication)

44. Sontheimer RD, Lieu TS, McCauliffe DP: Molecular characterization of the Ro/SS-A autoimmune response. Semin Dermatol 10:199-205, 1991

45. Boire G, Craft J: Biochemical and immunological heterogeneity of the Ro ribonucleoprotein particles. Analysis with sera specific for the RohY5 particle. J Clin Invest 84:270-279, 1989

46. Swanson MS, Nakagawa TY, LeVan, Dreyfuss G: Primary structure of human nuclear ribonuclear particle $C$ proteins: conservation of sequence and domain structures in heterogeneous nuclear RNA, mRNA and prerRNA-binding proteins. Mol Cell Biol 7:1731-1739,1987

47. Rokeach LA, Haselby JA, Hoch SO: Molecular cloning of a cDNA encoding the human Sm-D autoantigen. Proc Natl Acad Sci USA 85:4832-4836, 1988

48. Yamagata H, Harley JB, Reichlin, M: Molecular properties of the Ro/SS-A antigen and enzyme-linked immunosorbent assay for quantitation of antibody. J Clin Invest 74:625-633, 1984

49. Scopelitis E, Biundo JJ, Alspaugh MA: Anti - SS-A antibody and other antinuclear antibodies in systemic lupus erythematosus. Arthritis Rheum 23:287-293, 1980

50. Boire G, Craft J: Human Ro ribonucleoprotein particles: characterization of native structure and stable association with the La polypeptide.J Clin Invest 85:1182-1190, 1990

51. Harmon CE, Deng JS, Peebles CL, Tan EM: The importance of tissue substrate in the SS-A/Ro antigen-antibody system. Arthritis Rheum 27:166-173,1984

52. Wermuth DJ, Geoghegan WD, Jordon RE: Anti-Ro/SS-A antibodies. Association with a particulate (large, speckled-like thread) immunofluorescent nuclear staining pattern. Arch Dermatol 121:335-338, 1985

53. Elenitsas R, Bair LW, Medsger TA, Deng JS: Discordance of SS-A/Ro and SS-B/La cellular antigens in synchronized cells. J Invest Dermatol 87:504-509, 1986

54. Gaither KK, Fox OF, Yamagata H, Mamula MJ, Reichlin M, Harley JB: Implications of anti-Ro/Sjögren's syndrome A antigen autoantibody in normal sera for autoimmunity. J Clin Invest 79:841-846, 1987

55. Maddison PJ: ANA-negative SLE. Clin Rheum Dis 8:105-119,1982

56. Hendrick JP, Wolin SL, Rinke J, Lerner MR, Steitz JA: Ro small cytoplasmic ribonucleoproteins are a subclass of La ribonucleoproteins: 
further characterization of the Ro and La small ribonucleoproteins from uninfected mammalian cells. Mol Cell Biol 12:1138-1149, 1981

57. Bachmann M, Mayet WJ, Schroder HC, Pfeifer K, Neyer Zum Buschenfelde KH, Muller WEG: Association of La and Ro antigens with intracellular structures in HEp-2 carcinoma cells. Proc Natl Acad Sci USA 83:7770-7774, 1986

58. Wollina $U$, Beensen $H$, Kittler L, Schaarschmidt $H$, Knopf B: PUVA treatment of human cultured fiberglass from sclerotic skin enhances the binding of antibodies to SS-A (Ro). Arch Dermatol Res 279:206-208, 1987

59. Miyagawa S, Okada N, Inagaki $\mathrm{Y}$, Kitano $\mathrm{Y}$, Ueki H, Sakamoto $\mathrm{K}$, Steinberg ML: SSA/Ro antigen expression in simian virus 40-transformed human keratinocytes. J Invest Dermatol 90:342-345,1988

60. Koch GLE, Macer DRJ, Smith MJ: Visualization of the intact endoplasmic reticulum by immunofluorescence with antibodies to the major ER glycoprotein, endoplasmin. J Cell Sci 87:535-542, 1987

61. Itoh Y, Reichlin M: Molecular conformation and autoantibodies to the Ro/SSA particle. Arthritis Rheum 34(suppl):S101, 1991

62. Sontheimer RD, McCauliffe DP, Michalak M, Capra JD, Lieu TS: Cytoplasmic localization of a calcium-binding $46 \mathrm{kD}$ human Ro/SS-A antigen. Arthritis Rheum 33S:B15, 1990

63. Milner RE, Baksh S, Shemanko C, Carpenter MR, Smillie L, Vance JE, Opas M, Michalak M: Calreticulin, and not calsequestrin, is the major calcium binding protein of smooth muscle sarcoplasmic reticulum and liver endoplasmic reticulum. J Biol Chem 266:7155-7165, 1991

64. Kato N, Hoshimo H, Harada F: Nucleotide sequence of 4.5S RNA (C8 or hY5) from HeLa cells. Biochem Biophys Res Commun 108:363-370, 1982

65. Buyon JP, Ben-Chetrit E, Karp S, Roubey RAS, Pompeo L, Reeves WH, Tan EM, Winchester R: Acquired congenital heart block. Pattern of maternal antibody responses to biochemically denned antigens of the SSA/Ro-SSB/La system in neonatal lupus. J Clin Invest 84:627-634, 1989

66. Ben-Chetrit E, Fox RI, Tan EM: Dissociation of immune responses to the SS-A (Ro) 52-kD and 60-kD polypeptides in systemic lupus erythematosus and Sjögrens syndrome. Arthritis Rheum 33:349-355, 1990

67. Sontheimer RD: Subacute cutaneous lupus erythematosus. Clin Dermatol 3:58-68, 1985

68. Lee LA, David KM: Cutaneous Lupus erythematosus. Curr Probl Dermatol 1:161-200, 1989

69. LeFeber WP, Norris DA, Ryan SR, Huff JC, Lee LA, Kubo M, Boyce ST, Kotzin $\mathrm{BL}$, Weston WL: Ultraviolet light induces binding of antibodies to selected nuclear antigens on cultured human keratinocytes. J Clin Invest 74:1545-1551, 1984

70. Furukawa F, Kashihara-Sawami M, Lyons MB, Norris DA: Binding of antibodies to ENA SS-A/Ro and SS-B/La is induced on the surface of human keratinocytes by UVL: implications for the pathogenesis of photosensitive cutaneous lupus. J Invest Dermatol 94:77-85, 1990
71. Bachmann M, Chang SH, Slor H, Kukulies J, Muller WEG: Shuttling of the autoantigen La between nucleus and cell surface after UV irradiation of human keratinocytes. Exp Cell Res 191:171-180, 1990

72. Sontheimer RD, McCauliffe DP, Wilson JL, Capra JD: Transcriptional regulation of human calreticulin. Clin Res 40:493A, 1992

73. Kawashima T, Lieu TS, Capra JD, Sontheimer RD: Ultraviolet irradiation preferentially upregulated expression of the $46 \mathrm{kD}$ Ro/SS-A autoantigen (calreticulin) in transformed human epidermal keratinocytes (abstr). Clin Res 40:508A, 1992

74. Furukawa F, Lyons MB, Lee LA, Coulter SN, Norris DA: Estradiol enhances binding to cultured human keratinocytes of antibodies specific for SS-A/Ro and SS-B/La. J Immunol 141:1480-1488, 1988

75. Vanbruskirk A, Crump BL, Margoliash E, Pierce SK: A peptide binding protein having a role in antigen presentation is a member of the HSP70 heat shock family. J Exp Med 170:1799-1809, 1989

76. Fisch P, Malkovsky M, Kovats S, Strum E, Braakman E, Klein BS, Voss SD Morrissey LW, DeMars R, Welch WJ, Bolhuis RLH, Sondel PM: Recognition by human Vgamma9/Vdelta2 T cells of a GroEL homolog on Daudi Burkitt's lymphoma cells. Science 250:1269-1273, 1990

77. Hennungs H, Michael D, Cheng C, Steinert P, Holbrook K, Yuspa SH: Calcium regulation of growth and differentiation of mouse epidermal cells in culture. Cell 19:245-254, 1980

78. Lee LA, Gaither KK, Coulter SN, Norris DA, Harley JB: Pattern of cutaneous immunoglobulin $\mathrm{G}$ deposition in subacute cutaneous lupus erythematosus is reproduced by infusing purified anti-Ro (SS-A) autoantibodies in human skin-grafted mice. J Clin Invest 83:1556-1562,1989

79. Booth C, Koch GLE: Perturbation of cellular calcium induces secretion of luminal ER proteins. Cell 59:729-737, 1989

80. Lodish HF, Kong N: Perturbation of cellular calcium blocks exit of secretory proteins from rough endoplasmic reticulum. J Biol Chem 265:10893-10899,1990

81. Kutsch CL, Norris DA, Middleton MH, Lee LA: Induction of anti-Ro/SS-A antibody binding to human keratinocytes stimulated by either calcium ionophore A23187 or by TNF-alpha (abstr). J Invest Dermatol 96:610, 478, 1991

82. Schattner A, Rager-Zisman B: Virus-induced autoimmunity. Rev Infect Dis 12:204-222, 1990

83. Tesar TT, Armstrong J: Expression of Ro/SSA and La/SSB on epithelial cell surface following in vitro adenovirus infection (abstr). Arthritis Rheum S74, C20, 1986

84. Jianhui Z, Newkirk MM: Viral induction of the human autoantigen calregulin Ro/SS-A (abstr). Arthritis Rheumat 34(suppl):S102, 1991

85. Bachmann M, Falke D, Shroder HC, Muller WEG: Intranuclear distribution of the La antigen in CV-1 cells after herpes simplex virus type I infection compared with the localization of $U$ small nuclear ribonucleoprotein particles. J Gen Virol 70:881-891, 1989 